\title{
Aktivitas Antioksidan dan Toksisitas Asap Cair Dari Limbah Kulit Batang Mangrove Termodifikasi Kaolin Capkala
}

\author{
Fransiska Monita Wenisda ${ }^{1}$, Anthoni Batahan Aritonang ${ }^{*}$, Mega Sari Juane \\ Sofiana $^{1}$
}

1 Program studi Ilmu Kelautan, FMIPA, Universitas Tanjunpura, PontianakIndonesia

*Correspondence email: Anthoni B. Aritonang toniarios08@gmail.com

Received:26 September 2019- Accepted: 2 October 2019

Published: 31 October 2019 (C) Author(s) 2019. This article is open access

\begin{abstract}
Asap cair dari limbah kulit batang mangrove telah diproduksi menggunakan metode pirolisis pada suhu $400^{\circ} \mathrm{C}$ selama 6 jam. Selanjutnya asap cair diadsorpsi menggunakan kaolin yang diaktivasi secara termal pada suhu $500^{\circ} \mathrm{C}$. Analisa GC-MS (Gas Chromatography Mass Spectrophotometer) menunjukkan adanya beberapa senyawa dominan pada asap cair yaitu 2-furankarboksildehid, 2-propanon dan asam asetat. Aktivitas antioksidan asap cair dianalisis menggunakan metode DPPH (1,1-Diphenyl-2-picryl Hidrazil). Asap cair limbah kulit batang mangrove sebelum diadsorpsi memiliki aktivitas antioksidan (IC50 $=1635,65 \mathrm{ppm}$ ) lebih kuat dari asap cair limbah kulit batang mangrove setelah diadsorpsi $($ IC50 $=3023,06 \mathrm{ppm})$. Nilai IC50 tersebut menunjukkan asap cair memiliki aktivitas antioksidan sangat lemah. Hasil uji toksisitas asap cair limbah kulit batang mangrove sebelum diadsorpsi (LC50 $=562.341 \mathrm{ppm}$ ) dan asap cair limbah kulit batang mangrove setelah diadsorpsi (LC50 $=46.625 \mathrm{ppm}$ ). Nilai LC50 menunjukkan asap cair bersifat tidak toksik (LC50>1000 ppm).
\end{abstract}

Keywords: Asap Cair, Limbah Mangrove, Antioksidan, Toksisitas

\section{Pendahuluan}

Kawasan pesisir memiliki sumber daya hayati yang tinggi, termasuk mangrove yang telah banyak dimanfaatkan. Mangrove dimanfaatkan sebagai obat, bahan pangan, kayu bakar, dan arang (Rosyada et al., 2018). Industri arang dari mangrove di Kecamatan Batu Ampar menghasilkan limbah berupa kulit batang mangrove dan dapat mencemari lingkungan. Limbah kulit batang mangrove dapat diolah menjadi produk yang bernilai ekonomi tinggi yaitu menjadi asap cair.
Asap cair dapat digunakan sebagai pengawet makanan. Hal ini dikarenakan asap cair mengandung senyawa asam asetat, fenol, dan turunannya yang berpotensi sebagai bahan antioksidan sehingga menghambat proses oksidasi di dalam bahan makanan (Swastawati et al., 2008; Apituley et al., 2014; Sumpono et al., 2017). Asap cair kayu putih memiliki aktivitas antioksidan dengan nilai $\mathrm{IC}_{50}$ sebesar 9,77 ppm. Asap cair ini dapat menghambat laju peningkatan nilai TBA (Thiobarbituric Acid) dan asam lemak bebas pada pengolahan ikan tuna asap 
(Apituley et al., 2014). Asap cair cangkang buah karet memiliki aktivitas antioksidan dengan nilai $\mathrm{IC}_{50}$ sebesar $101,27 \mathrm{ppm}$ dan mampu menekan terjadinya ketengikan pada daging sapi (Sumpono et al., 2017). Cuka kayu dari mangrove Rhizopora apiculata dari Larut-Matang, Malaysia memiliki aktivitas antioksidan yang tinggi yaitu ditunjukkan dengan nilai $\mathrm{IC}_{50}$ sebesar 123,5 ppm (Loo et al., 2007).

Adsorpsi dapat mengurangi aroma asap dan intensitas warna pada asap cair. Asap cair yang diadsorpsi menggunakan arang aktif tempurung kelapa, arang aktif sekam padi, dan zeolit menunjukkan penurunan intensitas warna asap cair menjadi jernih dan dapat mengurangi bau menyengat (Kurniati et al., 2011; Kadir et al., 2014; Muflihati, 2016).

Kaolin merupakan salah satu jenis adsorben yang melimpah di Kalimantan Barat (Sari et al., 2016). Keunggulan kaolin sebagai adsorben ditunjang oleh sifat-sifat yang dimilikinya antara lain struktur permukaan yang bervariasi, stabil secara kimia dan mekanik, dan memiliki kapasitas pertukaran ion yang tinggi sehingga memiliki kemampuan adsorpsi yang baik (Bhattacharyya and Gupta, 2006).

Penggunaan asap cair pada pangan harus diuji toksisitasnya. Hal ini dilakukan untuk melihat tingkat keamanannya. Salah satu metode yang dapat digunakan untuk pengujian toksisitas yaitu BSLT (Brine Shrimp Lethality Test). Asap cair tempurung kelapa, serabut kelapa, dan kayu manis telah diuji toksisitasnya menggunakan metode BSLT. Hasilnya menunjukkan bahwa asap cair tersebut memiliki kandungan senyawa yang bersifat sangat toksik $\left(\mathrm{LC}_{50}<30 \mathrm{ppm}\right)$ (Budaraga et al., 2016). Asap cair dari biji salak memiliki toksisitas dengan nilai $\mathrm{LC}_{50}$ sebesar 23,44 ppm (Wagania et al., 2018).

Pada penelitian ini dilakukan pembuatan asap cair dari limbah kulit batang mangrove, asap cair yang dihasilkan selanjutnya diadsorpsi menggunakan kaolin teraktivasi. Penelitian ini bertujuan untuk mengetahui aktivitas antioksidan dan toksisitas asap cair limbah kulit batang mangrove sebelum dan setelah diadsorpsi.

\section{Metode}

\subsection{Waktu dan tempat}

Penelitian ini dilaksanakan pada bulan Februari sampai Mei 2019. Bahan baku asap cair berupa limbah kulit batang mangrove diperoleh dari Kecamatan Batu Ampar, Kabupaten Kubu Raya, Kalimantan Barat. Kaolin diperoleh dari Kecamatan Capkala, Kabupaten Bengkayang, Kalimantan Barat. Pembuatan asap cair dilakukan di Balai Riset dan Standarisasi Industri (Baristand) Pontianak. Analisis GC-MS asap cair dilakukan di Laboratorium Kimia Organik, Universitas Gadjah Mada. Analisis antioksidan dan toksisitas dilakukan di Laboratorium Riset dan Bioteknologi Fakultas Matematika dan Ilmu Pengetahuan Alam, Universitas Tanjungpura.

\subsection{Analisis Data \\ 2.3.1 Pe,buatan asap cair}

Limbah kulit batang mangrove ditimbang sebanyak $18 \mathrm{~kg}$. Sampel yang sudah ditimbang kemudian dimasukkan ke dalam reaktor pirolisis yang dilengkapi dengan rangkaian pendingin (kondensor). Hasil kondensasi kemudian di tampung. Proses pirolisis dilakukan mengacu pada metode Paskalia et al. (2017) yang dimodifikasi dengan suhu $400^{\circ} \mathrm{C}$ selama 6 jam. Asap cair yang diperoleh dipisahkan dari endapannya dengan cara disaring menggunakan kertas saring biasa. Supernatan yang diperoleh diadsorpsi menggunakan kaolin. Rendemen asap cair dihitung menggunakan persamaan sebagai berikut :

$$
R_{m}(\%)=\frac{B_{a c}}{B_{b b}} \times 100 \%
$$

Dengan $R_{m}$ merupakan rendemen dalam persentase, $B_{a c}$ adalah bobot asap cair dan $B_{b b}$ bobot bahan baku.

\subsection{Aktivasi fisika koalin}

Kaolin dicuci dengan akuades untuk menghilangkan pengotornya. Kaolin selanjutnya dikeringkan menggunakan oven pada suhu $100^{\circ} \mathrm{C}$. Kaolin dihaluskan dengan mortar dan diayak dengan ayakan ukuran 200 mesh. Kaolin yang telah halus kemudian dipanaskan pada suhu $500^{\circ} \mathrm{C}$ selama 1 jam menggunakan tanur (Sari et al., 2016 yang dimodifikasi).

\subsection{Adsorpsi asap cair dengan kaolin teraktivasi}

Asap cair diadsorpsi menggunakan kaolin teraktivasi. Kaolin sebanyak $10 \mathrm{~g}$ ditambahkan dengan asap cair sebanyak 100 
$\mathrm{mL}$, kemudian diaduk selama 15 menit pada suhu $60^{\circ} \mathrm{C}$ menggunakan hotplate stirrer dan disaring menggunakan kertas saring (Harianti, 2011).

\subsection{Analisis GC-MS}

Identifikasi komponen kimia asap cair menggunakan GC MS-QP2010S SHIMADZU. Analisis dilakukan di Laboratorium Kimia Organik FMIPA UGM. Kolom yang digunakan yaitu Rtx 5 MS dengan panjang $30 \mathrm{~m}$, diameter $0,25 \mathrm{~mm}$ dan ketebalan $0,25 \mu \mathrm{m}$. Suhu kolom $40^{\circ} \mathrm{C}$ selama 5 menit, kemudian ditingkatkan menjadi $300^{\circ} \mathrm{C}$ dan dipertahankan selama 15 menit. Suhu injektor diatur pada $310^{\circ} \mathrm{C}$. Gas helium digunakan sebagai gas pembawa dengan tekanan gas $13,0 \mathrm{kPa}$.

\subsection{Aktivitas antioksidan asap cair}

Analisis aktivitas antioksidan pada asap cair dilakukan menggunakan metode DPPH. Konsentrasi asap cair yang digunakan adalah 200; 400; 600; 800 dan 1.000 ppm. Asap cair diambil sebanyak $1 \mathrm{~mL}$, kemudian ditambahkan $1 \mathrm{~mL}$ larutan DPPH 100 ppm dan ditambahkan $2 \mathrm{~mL}$ metanol. Selanjutnya sampel diinkubasi pada suhu $37^{\circ} \mathrm{C}$ selama 30 menit di ruang gelap. Penghambatan senyawa radikal DPPH ditentukan menggunakan spektrofotometer UV-VIS pada panjang gelombang $521 \mathrm{~nm}$. Senyawa pembanding yang digunakan adalah asam askorbat dengan konsentrasi 2; 4; 6; 8 dan 10 ppm (Sumpono et al., 2017 yang dimodifikasi). Perhitungan \% Inhibisi menggunakan persamaan sebagai berikut :

$$
\% \text { inhibisi }=\frac{A b_{D P P H}-A b_{\text {sampel }}}{A b_{D P P H}}
$$

Dimana $A b$ merupakan Absorbansi.

Nilai $\quad L C_{50}$ diperoleh dengan menggunakan analisis probit. Suatu ekstrak dikatakan toksik bila memiliki nilai Nilai LC50 diperoleh dengan menggunakan analisis probit. Suatu ekstrak dikatakan toksik bila memiliki nilai $L C_{50} \leq 1000$ $\mu \mathrm{g} / \mathrm{mL} . \leq 1000 \mu \mathrm{g} / \mathrm{mL}$.

\subsection{Toksisitas asap cair}

Analisis toksisitas asap cair mengacu pada penelitian Budaraga et al. (2016). Sampel asap cair yang akan diuji ditambahkan air laut dengan variasi konsentrasi 12,$5 ; 25 ; 50$;
100 dan $500 \mu \mathrm{g} / \mathrm{mL}$. Air laut digunakan sebagai kontrol negatif. Artemia salina yang berumur 48 jam diambil sebanyak 10 ekor dan dimasukkan ke dalam vial, kemudian ditambahkan asap cair hingga volumenya menjadi $5 \mathrm{~mL}$. Setiap konsentrasi dilakukan 3 kali pengulangan. Pengamatan dilakukan setelah 24 jam dengan menghitung jumlah A. salina yang masih hidup dan yang sudah mati, kemudian dihitung mortalitasnya dengan persamaan berikut :

$\%$ Mortalitas $=\frac{A A_{s m}}{A A_{s m}+A A_{s h}} \times 100 \%$

Dimana $A A_{s m}$ merupakan Akumulasi A. Salina mati dan $A A_{s h}$ adalah Akumulasi A. Salina hidup.

\section{Hasil dan Pembahasan}

\subsection{Pirolisis asap cair}

Sampel limbah kulit batang mangrove dengan berat $18 \mathrm{~kg}$ dicacah dan dimasukkan ke dalam reaktor pirolisis (Gambar 1). Suhu pirolisis yang digunakan pada penelitian ini yaitu $400^{\circ} \mathrm{C}$, hal ini dikarenakan pada suhu tersebut asap cair yang dihasilkan memiliki senyawa yang mempunyai kualitas organoleptik yang baik (Girard, 1992).

Asap cair yang dihasilkan berwarna cokelat kehitaman dan memiliki bau asap yang menyengat. Asap cair yang diperoleh pada penelitian ini sama dengan asap cair yang dihasilkan pada penelitian Lestari et al. (2015), yang mengatakan bahwa asap cair yang dihasilkan berwarna hitam pekat kecokelatan dan berbau. Rendemen asap cair yang diperoleh yaitu 34\% dengan volume asap cair sebesar $6.090 \mathrm{~mL}$.

\subsection{Struktur komunitas vegetasi mangrove}

Asap cair dari proses pirolisis masih mengandung tar berupa endapan berwarna hitam. Tar dapat dipisahkan dari asap cair dengan penyaringan (Lestari et al., 2015). Asap cair yang telah terpisah dari tar selanjutnya diadsorpsi menggunakan kaolin yang bertujuan menghilangkan aroma asap dan intensitas warna pada asap cair.

Kaolin yang digunakan pada penelitian, sebelumnya diaktivasi dengan cara pemanasan pada suhu $500^{\circ} \mathrm{C}$. Pemanasan bertujuan untuk menguapkan air yang terjerap pada kaolin, sehingga pori-pori 
kaolin bertambah luas dan daya adsorpsinya semakin meningkat (Sari et al., 2016).

Asap cair kulit batang mangrove sebelum diadsorpsi (ACM) berwarna cokelat kehitaman. Asap cair mengalami perubahan warna setelah diadsorpsi menggunakan kaolin (ACMK) menjadi warna abu-abu jernih (Gambar 2). Bau menyengat pada asap cair ini sedikit berkurang setelah diadsorpsi. Hal ini diduga berkurangnya tar dan senyawa-senyawa yang terkandung dalam asap cair.

\subsection{Analisis GC-MS Asap Cair}

Hasil GC-MS pada asap cair limbah kulit batang mangrove sebelum dan setelah diadsorpsi menunjukkan tidak ditemukan senyawa PAH. Hal ini dikarenakan kandungan $\mathrm{PAH}$ dalam asap dapat dikurangi 10 kali lipat jika suhu pirolisis $300^{\circ} \mathrm{C}-400^{\circ} \mathrm{C}$ (Stolyhwo and Sikorski, 2005). Senyawa PAH adalah senyawa yang bersifat karsinogenik dimana implikasinya terhadap kanker payudara dan paru-paru telah dibuktikan pada hewan percobaan (Kadir et al., 2011).

Perbedaan komposisi jumlah kandungan senyawa pada asap cair (Tabel 1) dikarenakan beberapa senyawa dominan pada asap cair kulit batang mangrove teradsorpsi pada pori kaolin sehingga mempengaruhi \% area dari senyawa yang lain. Haji et al. (2007) menyatakan bahwa kandungan senyawa kimia yang terdapat di dalam asap cair sangat bergantung pada kondisis pirolisis dan bahan baku yang digunakan.

\subsubsection{Tingkat pancang}

Struktur vegetasi mangrove ditingkat pancang, disajikan pada Tabel 3. Jenis mangrove pada tingkat pancang juga didominasi oleh genus Avicenniaceae, dengan ditemukannya pada 3 stasiun pengamatan kecuali stasiun 3 . Jenis yang hanya ditemukan pada stasiun 3 yaitu N.frutican tidak tergolong dalam tingkatan pancang. Jenis $A$. lanata memiliki nilai penting (INP) yang tinggi pada stasiun 4, hal ini menunjukkan tingkat adaptasi Avicennia yang baik di stasiun 4. Pada tingkatan pancang di stasiun 1 dan 4, kerapatan tinggi pada genus Avicenniaceae menunjukkan bahwa komunitas vegetasi tersebut berada pada kondisi yang tidak mengalami gangguan (Fadli, 2014).

\subsubsection{Tingkat pohon}

Struktur vegetasi tingkat pohon disajikan pada Tabel 4. Stasiun 1 merupakan stasiun yang berhadapan dengan laut, vegetasi mangrove tingkat pohon pada stasiun 1 didominasi oleh $A$. marina, hal ini menunjukkan bahwa $A$. marina sangat adaptif terhadap kondisi dengan salinitas yang tinggi. Avicennia merupakan genus yang memiliki kemampuan toleransi terhadap kisaran salinitas yang luas dibandingkan dengan genus lainnya. $A$. marina mampu tumbuh dengan baik pada salinitas yang mendekati tawar sampai dengan 90\% (Susanto, 2011). Hal ini juga disebabkan karena penyebaran biji jenis A. marina merata di zona depan yang memiliki kandungan substrat berlumpur agak lembek yang mendukung pertumbuhan dan kerapatan jenis A. marina pada tingkat semai dan pancang, sehingga kerapatan tingkat semai dan pancang lebih tinggi dari jenis mangrove yang lain (Hotden, 2013).

Stasiun 2 didominasi oleh $A$. alba dengan nilai penting (INP) sebesar 164, $47 \%$. Stasiun 3 didominasi oleh $\mathrm{N}$. frutican, hal ini dikarenakan adanya pengaruh sainitas yang kurang sehingga $\mathrm{N}$. frutican dapat tumbuh dengan baik. Tanaman tumbuh rapat bersama, seringkali membentuk komunitas murni yang luas di sepanjang sungai dekat muara hingga sungai dengan air payau (Kitamura et al., 1997). Stasiun 4 masih ditemukan adanya genus Avicennia, dikarenakan substrat yang sesuai sehingga memungkinkan pertumbuhannya dengan baik walau dengan kadar salinitas yang tidak terlalu tinggi.

Menurut Saparinto (2007), mangrove bergantung pada air laut (pasang), air tawar, dan endapan lumpur sebagai sumber hara. Berdasarkan hasil yang didapat, tidak terbentuknya zonasi pada muara sungai Peniti. Hal ini dikarenakan adanya faktor manusia yaitu penebangan hutan yang dilakukan pada saat pembukaan lahan industri, namun pembanguan industri tersebut hingga kini belum terealisasikan. Akibat adanya penebangan hutan yang dilakukan berdampak pada menurunnya keanekaragaman spesies yang ada di muara sungai Peniti.

\section{Ucapan Terima Kasih}


Penulis mengucapkan terimakasih kepada pihak Community Development and Outreaching Universitas Tanjungpura yang telah memberikan bantuan beasiswa kepada penulis sehingga dapat menyelesaikan studi S1, maupun kepada semua pihak yang terlibat secara langsung maupun tidak dari penelitian ini hingga telah didapatkan hasil yang semoga bermanfaat bagi akademisi maupun penggiat pesisir.

\section{Daftar Pustaka}

Alik, T, S, D; Umar, M, R; Priosambodo, D, 2012, Analisis Vegetasi Mangrove Di Pesisir Pantai Mara'bombang - Kabupaten Pinrang.

Fadli; Khairijon; Sofiyanti, N, 2014, Analisis Vegetasi Avicennia Sp. dan Karakteristik Sedimen Di Kawasan Mangrove Desa Sungai Rawa Kecamatan Sungai Apit Kabupaten Siak, Riau.

Habdiansyah, P; Lovadi, I; Linda, R, 2015, Profil Vegetasi Mangrove Desa Sebubus Kecamatan Paloh Kabupaten Sambas, J. Protobiont, 4(2):9-17.

Hotden; Khairijon; Isda, M, N; 2013, Analisis Vegetasi Mangrove Di Ekosistem Mangrove Desa Tapian Nauli I Kecamatan Tapian Nauli Kabupaten Tapanuli Tengah Provinsi Sumatera Utara, JOM FMIPA, 1.

Kitamura, S; Anwar, C; Chaniago, A; Baba, S, 1997. Handbook of Mangroves in Indonesia-Bali and Lombok. Depertement of Sustanable Mangrove Project.

Marini; Kushadiwijayanto, A, A; Nurrahman, Y, A, 2018, Struktur Komunitas Hutan Mangrove Di Desa Sungai Bakau Kecil Kabupaten Mempawah Kalimantan Barat, J. Khatulistiwa.

Nurrahman, Y, A; Djunaedi, O, S; Rostika, R, 2012, Struktur dan Komposisi Vegetasi Mangrove di Pesisir Kecamatan Sungai Raya Kepulauan Bengkayang Kalimantan Barat, J. Perikanan dan Kelautan, 3(1):99-107.

Onrizal, 2008, Panduan Pengenalan dan Analisis Vegetasi Hutan Mangrove, Departemen Kehutanan, Fakultas Pertanian, Universitas Sumatera Utara, Sumatera Utara.

Prastomo, R, H; Herawatiningsih, R; Latifah, S, 2017, Keanekaragaman Vegetasi Di Kawasan Hutan Mangrove Desa Nusapati Kabupaten Mempawah, Jurnal Hutan Lestari, $5(2): 556-562$

Rudiansyah, D.; Rahmawati.; Rafdinal, 2017, Eksplorasi Bakteri Selulolitik dari Tanah Hutan Mangrove Peniti, Kecamatan Segedong, Kabupaten Mempawah, J. Protobiont., 6(3):255-262

Saparinto, C. 2007. Pendayagunaan Ekosistem Mangrove. Penerbit Dahara Prize. Semarang, 2007
Susanto, A, H; Soedarti, T; Purnobasuki, H, 2011, Struktur Komunitas Mangrove Di Sekitar Jembatan Suramadu Sisi Surabaya. 